\title{
Z Research Square \\ Detection of Breast Cancer Related Gene Polymorphisms By a New Modified PCR-RAPD-PCR Technique
}

Zainab Zamil gataa Allami

University of Misan

Maytham A Dragh ( $\square$ maithamdragh@uomisan.edu.iq)

University of Misan

\section{Research Article}

Keywords: polymorphism, Iraqi, breast cancer, drug resistance gene, tumor suppressor gene, estrogen receptor a gene, regulatory gene

Posted Date: January 19th, 2022

DOI: https://doi.org/10.21203/rs.3.rs-1095491/v1

License: () (7) This work is licensed under a Creative Commons Attribution 4.0 International License. Read Full License 


\section{Abstract}

Breast cancer is one of the most aggressive cancers with high estimated mortality worldwide; many studies around the world have involved polymorphisms in drug resistance genes, tumor suppressor genes, estrogen receptor genes, and regulatory genes related to the development and prognosis of breast cancers. It is worth noting that this study was the first to include these genes as PCR templates to determine the relationship between their polymorphisms and breast cancer incidence using RAPD of amplified genes. The study was designed first to evaluate the association of $A B C G 2, A B C B 1$ and $B R C A 1 \mathrm{gene}$ polymorphisms in addition to miRNA-152 and ER-a using the RAPD technique with breast cancer incidence in women in Maysan, Province and then to employ those genes in the future as biomarkers in breast cancer prediction and diagnosis. This study included 100 patients with breast cancer and 30 healthy control women, and then all samples were amplified by conventional PCR with specific $\mathrm{F}$ and $\mathrm{R}$ primers for $A B C G 2, A B C B 1, B R C A 1, E R-a$, and miRNA-152 genes. Then, the best PCR product

(20) was chosen as the template for the RAPD technique. The results revealed that all RAPD primers showed polymorphisms with higher values in patient samples, and revealed several mutations in patient samples. Our study proved the relationship between genetic polymorphisms of breast cancer related genes and a higher incidence of cancer. The results of the statistical analysis by using Chi-square showed that there were no significant differences in the types of bands of the $A B C G 2, A B C B 1, B R C A 1$ between the patient sample and the control sample, at the probability level of $\mathrm{P}>0.05$, and significant differences in the types of bands of the ER- $a$, and mi-RNA 152 between the patient sample and the control sample, at the probability level of $\mathrm{P}<0.05$. The current study recommends employing these results for future prediction and diagnosis of breast cancers.

\section{Introduction}

Cancer is a group of diseases involved in abnormal growth of cell with potential spread to other parts of the body (Chandira et al., 2019). Breast cancer (BC) is the most common cancer in women around the world, accounts for $15 \%$ of cancer deaths among women, and is the leading cause of cancer death in females worldwide (Jin .,2020). In Iraq, breast cancer is the most common pattern of female malignancy, accounting for approximately one-third of the registered female cancers according to the Iraqi cancer registry in 2004 (Mohammed., 2011; Ismaeel., 2013). Some forms of cancer are associated with a family history of the disease, but in most instances, there is no definitive pattern of inheritance is observed (Sas-Korczyriska et al., 2017; Mampunye., 2020).

Many genes are found related to breast cancer (Sun et al., 2017). The susceptible genes are critical risk factors for both hereditary and sporadic breast cancer (Xie., 2020). ABCB1 gene is located on chromosome 7q21.12 (Sheng X et al., 2012; MUTLU içDUYGU et al., 2020). ABCB1 encoding a transmembrane glycoprotein called permeability glycoprotein (P-gp), the physiologic role of P-gp an ATP-driven transporter mediates to transport many metabolites and harmful substances from inside to outside through plasma membrane (Abuhaliema et al., 2016; MUTLU içDUYGU et al., 2020). ABCG2 gene is located on human chromosome at the locus $4 q 22.1$. The genetic variants of the ATP-binding cassette, superfamily $\mathrm{G}$, member 2 ( $A B C G 2)$ is known to be involved in developing cancer risk and interindividual differences in chemotherapeutic response

(Wu et al., 2015). BRCA1 is situated on chromosome 17q21 (Rebbeck et al., 2016 ; Ndiaye et al., 2020) ; is the major cause of familial breast cancer( ALHannan et al., 2019); BRCA1 gene is produce tumor suppressor proteins, so that its called as (TSGs gene), any changes or mutations in BRCA1 gene can lead to an increased risk of developing breast, ovarian, and prostate cancer (Ayub et al., 2014; Mehrgou and Akouchekian., 2016). ER-a gene is located on chromosome 6q25.1, Estrogen receptor alpha (ER-a) is plays important role in development and progression of cancer, it also stimulates breast epithelial tissue proliferation and differentiation through combining with estrogen (Abd Ellatif et al., 2016; AL-Amri et al., 2020). miRNA-152 gene is situated on chromosome 17q21.32 (Zhou et al., 2012 ; Liu et al.,2016), miRNAs can regulate gene expression at the posttranscriptional level by repressing translation of protein coding gene, miRNA-152 is abnormally expressed in a variety of diseases, including various cancers, more evidence suggests that miRNA-152 is a tumor suppressor related to cell proliferation, migration, and invasion of human cancer (Kindrat et al., 2016).

RAPD can be defined as a DNA fingerprinting technique based on polymerase chain reaction amplification of random fragments of genomic DNA with single short primers of arbitrary nucleotide sequences (Kumar and Guru Subramanian, 2011; Sharma and Singh, 2017). RAPD analysis is used in studies in the field of genetic instability in breast cancer (Novikov et al., 2016). In this study, we performed a new procedure with some modifications to the traditional RAPD technique when we used the amplified gene as a template in RAPD. This procedure resulted in more accuracy and yielded more specific data. We named it PCR-RAPD-PCR (PRP). The aim of this study was to evaluate the genetic polymorphism of the BC gene in women with breast cancer in Maysan Province, southern Iraq.

\section{Material And Methods}

\section{Study sites}

All methods were carried out in accordance with relevant guidelines and regulations. The experimental protocols were approved by ethics committee/IRB [scientific committee of Biology Department/college of science/Misan university]. The study was undertaken in the genetic engineering laboratory/ Department of Biology / College of science/Misan University. A total of (100) blood samples were collected from the breast cancer women patients and ( 30 ) healthy in Maysan Health Directorate/AL-Sader Teaching Hospital /AL-Shifa Tumor Treatment Center in/ AL-Amarah city (sub-districts of Maysan province/south of Iraq ).

\section{Samples collection and identification}

100 blood samples $(2-3 \mathrm{~mL}$ ) were collected from each breast cancer female patient (in case patient woman in good healthy) or blood samples (1 $\mathrm{mL}$ ) were collected from each breast cancer patient woman (in case the patient woman in critical condition). Blood samples were collected from each woman patient 
through the median cubital vein or carpel veins (according to a health condition) into EDTA containing tubes and were stored at -20 •C till DNA extraction.

\section{Genomic DNA isolation}

All samples were collected from the breast cancer women patients at a different time for three months (September to November). All samples were kept under the same condition. DNA was extracted from whole blood by using the gSYNCTM DNA Extraction Kit Functional Test Data (Geneaid, Taiwan).

\section{Column purification}

Genomic DNA was isolated from blood sample. The amount of isolated DNA was varied from 52.392 to $88.712 \mathrm{ng} / \mu \mathrm{l}$ and an absorbance ratio of A260/280 was obtained in the range of $1.71-1.98$.

\section{Polymerase chain reaction for isolated PCR product (specific BC genes)}

Isolated DNA from all 100 women BC Patient and 30 normal ; genomic DNA samples were prepared by pooling the same amount of genomic DNA from each individual. The DNA fragments of the PCR product of BC genes were amplified through the polymerase chain reaction technique. The following components: $2.5 \mu$ l primer $F, 2.5 \mu l$ primer $R, 2.5 \mu l$ Nuclease free

water, $12.5 \mu \mathrm{l} \mathrm{GO}$ Taq ${ }^{\circledR} \mathrm{G} 2$ Green master mix and $5 \mu$ l DNA template were added for each 25 reaction mixture. The primer sequences are shown in the Table 1.

Table (1) Sequence of ABCG2, ABCB1, BRCA1, miRNA-152, and ER-a primers, GC\% and length

\begin{tabular}{|llllll|}
\hline primer & Sequence & GC\% & Length (Base) & References \\
\hline ABCG2 & 5-AAAT GTTCATAG CCAGTTTCTTGGA-3 & $35.29 \%$ & F:25 & R:26 & Wu et al.,2015 \\
& 3-ACAGTAATGTCGAAGTTTTTA TCGCA-5 & & & & \\
\hline ABCB1 & 5-TTGATGGCAAAG AAATAAAGC-3 & $40.47 \%$ & F:21 & R:21 & Tazzite et al., 2016 \\
& 3-CTTACATTAGGCAGTGAC TCG-5 & & & & \\
\hline BRCA1 & 5-CAC CTC CAA GGT GTA TGA AG-3 & $50 \%$ & F:20 & R:22 & Gholipoorfeshkechen and \\
& 3-CTC TAG GAT TCT CTG AGC ATG G-5 & & & & Arjunan.,2014 \\
miRNA- & 5-TCTGTCATGCACTGACTGCTC-3 & $53.65 \%$ & F:21 & R:20 & Nguyen-Dien et al .,2014 \\
152 & 3GGGCATGCTTCTGGAGTCTA-5 & & & & \\
\hline ER- $a$ & 5-ATG CGC TGC GTC GCC TCTAA-3 & $60 \%$ & F:20 & R:20 & Sato et al .,2008 \\
\hline 3-CTG CAG GAA AGG CGA CAG CT-5 & & & & \\
\hline
\end{tabular}

The PCR reaction consisted of 35 cycles following three essential steps: initial denaturation ( 5 min at $94 \circ \mathrm{C}$ ), DNA denaturation ( 1 min at $94 \circ \mathrm{C}$ ), primer annealing ABCG2 (45 sec at gradient $53.5-58.5 \circ \mathrm{C}$ ), primer annealing ABCB1 (45 sec at $53 \circ \mathrm{C}$ ), primer annealing BRCA1 (45 sec at $55 \circ \mathrm{C}$ ), primer annealing ER-a (45 sec at gradient 52-58 ॰C), primer annealing miRNA -152 (15 sec at $65 \circ \mathrm{C})$, and primer extension ( 1 min at $72 \circ \mathrm{C})$. There was a Final extension cycle for $7 \mathrm{~min}$ at $72 \circ \mathrm{C}$. The size of the amplified PCR product was subjected to electrophoresis in $1.2 \%$ agarose gel, $1 \mathrm{X}$ TBE buffer with ethidium bromide $2 \%$, at 80 $\checkmark$ for $60 \mathrm{~min}$. The bands were visualized under ultraviolet trans-illumination and photographed in Gel- Doc equipment. The PCR product that having a clear band was later used as a template in the PCR-RAPD-PCR Technique.

\section{Purify PCR Product by gel extraction}

PCR products were obtained after a conventional PCR run; PCR products were extracted from an agarose gel after gel electrophoresis for breast cancer-related genes by using the E.Z.N.A.® Gel Extraction kit protocol (OMEGA BIO-TEK ,USA).

\section{Column Purification}

PCR product (specific gene) was isolated from the DNA gel extraction ,the amount of isolated DNA PCR product ( specific gene) was varied from 52.392$88.712 \mathrm{ng} / \mu \mathrm{l}$ and absorbance ratio of A260/280 was obtained in the range of 1.71-1.98.

\section{PCR-RAPD-PCR Technique}

The isolated PCR product from all women BC Patient and normal DNA; the same best 40 PCR product (20 patient and 20 control) of $A B C G 2, A B C B 1, B R C A 1$, ER- $a$, and miRNA-152 genes were chosen for PCR-RAPD-PCR. The RAPD primer sequencing in the PCR-RAPD-PCR as shown in the Table 2. 
Table 2

Sequence of RAPD primers, GC\% and length

\begin{tabular}{|llll|}
\hline RAPD primers & Primers Sequences & GC\% & Length (Base) \\
\hline OPAA11 & 5-ACCCGACCTG-3 & $80 \%$ & 10 Base \\
\hline OPU15 & 5-ACGGGCCAGT -3 & $70 \%$ & 10 Base \\
\hline OPAA17 & 5-GAGCCCGACT -3 & $\% 70$ & 10 Base \\
OPD18 & 5-GAGAGCCAAC- 3 & $\% 60$ & 10 Base \\
\hline
\end{tabular}

The reaction mixture $(20 \mu \mathrm{L})$ consisted of template PCR product $2.5 \mu \mathrm{l}, 2.5 \mu \mathrm{L}$ (OPAA11, OPU15, OPAA17, OPD18) RAPD primer, 7.5 $\mu$ l Nuclease free water, and

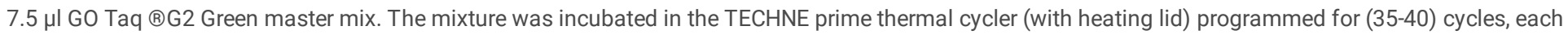
one consisting of as following: a denaturation step ( $1 \mathrm{~min}$ at $94 \circ \mathrm{C})$, one annealing step (30 sec at gradient $36-39 \circ \mathrm{C})$ and an extension step $(1 \mathrm{~min}$ at $72 \circ \mathrm{C})$. After the cycling, a final extension for $1.30 \mathrm{~min}$ at $72 \circ \mathrm{C}$ was followed by slow cooling to $10 \circ \mathrm{C}$. Four RAPD primers: (OPAA11, OPU15,

OPAA17, and OPD18) were used in the amplifications. The primers were obtained from the company of AUGCT DNA SYN Biotechnology /china.

\section{Electectrophoretic analysis}

The reaction products were separated by electrophoresis on an agarose gel ( $2 \%$ ) containing ethidium bromide ( $2 \%)$ were prepared in 1 X TBE buffer. The DNA ladder size marker used in this study contained many discrete bands (in base pair) 1500, 1000, 900, 800, 700, 600, 500, 400, 300, 200,100,75,50 and 25 bp from nearest distance to the well to the far one from the well respectively. This ladder was used as a molecular size indicator in the experiments of this study. The DNA fragments obtained were visualized under ultraviolet light and the molecular sizes of DNA bands were estimated according to standard curve represented the relationship between band molecular size of the ladder measured by base pairs and distance of migration bands (Sambrook and Russell., 2006).

\section{Statistical analysis}

The relationship between the polymorphic, monomorphic, and unique band and RAPD primer of the breast cancer patient and control was assessed by using the $\mathrm{X}^{2}$ test, $\mathrm{P} \leq 0.05$ was considered statistically significant.

\section{Results}

The results of the DNA gel extraction of PCR product are showed that the amount DNA of PCR product (specific gene) ranged from 52.3.92-88.712 ng / $\mu$ l and absorbance ratio of A260/280 was obtained in the range of 1.71-1.98 nm which is within the normal range which between $1.7-2.0 \mathrm{~nm}$ which was detected by the NanoDrope device. The results of the DNA gel extraction are showed the success of the specific gene amplification process. Therefore, PCR products can be used instead of DNA as a template in the RAPD technique. Therefore, this technique is called PCR-RAPD-PCR (PRP).

The results of the electrophoresis of the BC gene (PCR product) by using RAPD primers showed a clear difference in the number of amplified gene bands and a clear difference in their molecular weights, depending on the primer used. The four primers OPAA11, OPU15, OPAA17, and OPD18 were used to study the possibility of determining the genetic polymorphisms of the $A B C G 2, A B C B 1, B R C A 1, E R-a$, and mi-RNA 152 genes between the patient and the control group. The results of the study of genetic polymorphisms in the two groups depended on the presence or absence of bands resulting from the amplification of certain segments of the genes of samples and the molecular weights of those bands. The results of gene amplification showed that all primers (OPAA11, OPU15, OPAA17, and OPD18) amplified the $A B C G 2, A B C B, B R C A 1, E R-a$, and mi-RNA-152 gene of the patient and the control group and type of band was determined depending on the size and site of the bands in the field of the gel, as shown in the figure 1.

In our current study, our results showed that the total number of total bands of $A B C G 2$ in the patient group was 214 band, the primer OPAA 11 was given the highest number of bands 58 bands out of the total bands, in the patient group the OPU15 has the highest efficiency 0.028 . It is noted that this primer gave the highest percentage of polymorphisms amounted to 10.714 with a primer discriminatory power of $40 \%$, which is the highest discriminatory power, while with the control group the primer OPAA11 gave the highest number of polymorphic band 6 bands and it has the highest efficiency 0.037 . It is noted that this primer gave the highest percentage of polymorphisms amounted to 13.333 with a primer discriminatory power $42.85 \%$, which is the highest discriminatory power. Our results showed that the total number of total bands of $A B C B 1$ gene in the patient sample was 215 band, the primer OPAA11 was given the highest number of bands 57 bands out of the total bands. in the patient group, the primer OPD18 has the highest primer efficiency 0.037 . It is noted that this primer gave the highest percentage of polymorphisms amounted to 15.0943 with a primer discriminatory power of $32 \%$, which is the highest discriminatory power, Compared with control sample OPAA11, OPU15, and OPD 18 have the highest efficiency 0.035 , it is noted that the primer OPU15 was given the highest percentage of polymorphisms amounted to 18.1818 with a primer discriminatory power of $30.76 \%$, which is the highest discriminatory power. our results showed that the total number of total bands of BRCA1 gene in patient sample was 206 band, the primer OPU 15 was gave the highest number of bands (68) bands out of the total bands, in the patient group, the OPD18 primer has the highest efficiency 0.029 . It is noted that this primer gave the highest percentage of polymorphisms amounted to $14.285 \%$ with a primer discriminatory power of $31.57 \%$, which is the highest discriminatory power, compared with the control group the primer OPAA11 and OPAA17 have the highest primer efficiency 0.023 . It is noted that the OPAA17 primer gave the highest percentage of polymorphisms amounted to 10.3448 with a primer discriminatory power of $37.5 \%$, which is the highest discriminatory power, as shown in table 3,4 and figure (2). 
Table (3) The numbers and percentages of the total band ,polymorphic ,unique ,monomorphic band, and primer efficiency and primer discriminatory power that produced from amplified four primer RAPD in $A B C G 2, A B C B 1$, and $B R C A 1$ gene of patient sample.

\begin{tabular}{|c|c|c|c|c|c|c|c|c|c|}
\hline Gene & $\begin{array}{l}\text { RAPD } \\
\text { Primer }\end{array}$ & $\begin{array}{l}\text { Total No. } \\
\text { of bands }\end{array}$ & $\begin{array}{l}\text { Total No. of } \\
\text { polymorphic bands }\end{array}$ & $\begin{array}{l}\text { Polymorph } \\
\% \text { ism }\end{array}$ & $\begin{array}{l}\text { Primer } \\
\text { efficiency }\end{array}$ & $\begin{array}{l}\text { Primer } \\
\text { discriminato ry } \\
\text { power \% }\end{array}$ & $\begin{array}{l}\text { Total No. of } \\
\text { unique bands }\end{array}$ & $\begin{array}{l}\text { Uniqueness, } \\
\%\end{array}$ & $\begin{array}{l}\text { Total No. } \\
\text { of } \\
\text { Monomorp } \\
\text { hic bands }\end{array}$ \\
\hline ABCG2 & OPAA11 & 58 & 4 & 6.8965 & 0.018 & 26.66 & 1 & 1.724 & 3 \\
\hline \multirow[t]{3}{*}{ Patient } & OPU 15 & 56 & 6 & 10.714 & 0.028 & 40 & 0 & 0 & 3 \\
\hline & OPAA17 & 46 & 3 & 6.5217 & 0.014 & 20 & 5 & 10.86 & 3 \\
\hline & OPD 18 & 54 & 2 & 3.7037 & 0.009 & 13.33 & 4 & 7.407 & 3 \\
\hline Total & & 214 & 15 & 7.1770 & & & 10 & 4.784 & 12 \\
\hline ABCB1 & OPAA11 & 57 & 6 & 10.5263 & 0.027 & 24 & 2 & 3.5087 & 1 \\
\hline \multirow[t]{3}{*}{ Patient } & OPU 15 & 51 & 5 & 9.80392 & 0.023 & 20 & 1 & 1.9607 & 1 \\
\hline & OPAA17 & 54 & 6 & 11.111 & 0.027 & 24 & 2 & 3.7037 & 1 \\
\hline & OPD 18 & 53 & 8 & 15.0943 & 0.037 & 32 & 3 & 5.6603 & 1 \\
\hline Total & & 215 & 25 & 11.6279 & & & 8 & 3.7209 & 4 \\
\hline BRCA1 & OPAA11 & 51 & 3 & 5.8823 & 0.014 & 15.78 & 3 & 5.88235 & 3 \\
\hline \multirow[t]{3}{*}{ Patient } & OPU 15 & 68 & 5 & 7.3529 & 0.024 & 26.31 & 3 & 4.41176 & 3 \\
\hline & OPAA17 & 45 & 5 & 11.11 & 0.024 & 26.31 & 2 & 4.4444 & 3 \\
\hline & OPD 18 & 42 & 6 & 14.285 & 0.029 & 31.57 & 3 & 7.14285 & 3 \\
\hline Total & & 206 & 19 & 9.2233 & & & 11 & 5.3398 & 12 \\
\hline
\end{tabular}

Table (4) The numbers and percentages of the total band ,polymorphic ,unique ,monomorphic band, and primer efficiency and primer discriminatory power that produced from amplified four primer RAPD in $A B C G 2, A B C B 1$, and $B R C A 1$ gene of control (healthy) sample.

\begin{tabular}{|c|c|c|c|c|c|c|c|c|c|}
\hline Gene & $\begin{array}{l}\text { RAPD } \\
\text { Primer }\end{array}$ & $\begin{array}{l}\text { Total No. } \\
\text { of bands }\end{array}$ & $\begin{array}{l}\text { Total No. of } \\
\text { polymorphic bands }\end{array}$ & $\begin{array}{l}\text { Polymorphism } \\
\%\end{array}$ & $\begin{array}{l}\text { Primer } \\
\text { efficiency }\end{array}$ & $\begin{array}{l}\text { Primer } \\
\text { discriminatory } \\
\text { power \% }\end{array}$ & $\begin{array}{l}\text { Total No. } \\
\text { of unique } \\
\text { bands }\end{array}$ & $\begin{array}{l}\text { Uniqueness, } \\
\%\end{array}$ & $\begin{array}{l}\text { Total No. of } \\
\text { Monomorp } \\
\text { hic bands }\end{array}$ \\
\hline ABCG2 & OPAA11 & 45 & 6 & 13.333 & 0.037 & 42.85 & 2 & 4.4444 & 4 \\
\hline \multirow[t]{3}{*}{ Control } & OPU15 & 39 & 4 & 10.256 & 0.024 & 28.57 & 2 & 5.1282 & 4 \\
\hline & OPAA17 & 40 & 2 & 5 & 0.012 & 14.28 & 0 & 0 & 4 \\
\hline & OPD18 & 38 & 2 & 5.2631 & 0.012 & 14.28 & 2 & 5.2631 & 4 \\
\hline Total & & 162 & 14 & 8.6419 & & & 6 & 3.7037 & 16 \\
\hline ABCB1 & OPAA11 & 32 & 4 & 12.5 & 0.035 & 30.76 & 0 & 0 & 1 \\
\hline \multirow[t]{3}{*}{ Control } & OPU15 & 22 & 4 & 18.1818 & 0.035 & 30.76 & 1 & 4.5454 & 1 \\
\hline & OPAA17 & 26 & 1 & 3.84615 & 0.008 & 7.69 & 2 & 7.6923 & 1 \\
\hline & OPD18 & 34 & 4 & 11.7647 & 0.035 & 30.76 & 0 & 0 & 1 \\
\hline Total & & 114 & 13 & 11.4035 & & & 3 & 2.6315 & 4 \\
\hline BRCA1 & OPAA11 & 42 & 3 & 7.14285 & 0.023 & 37.5 & 1 & 2.38095 & 3 \\
\hline \multirow[t]{3}{*}{ Control } & OPU 15 & 30 & 2 & 6.66666 & 0.015 & 25 & 2 & 6.66666 & 3 \\
\hline & OPAA17 & 29 & 3 & 10.3448 & 0.023 & 37.5 & 1 & 3.44827 & 3 \\
\hline & OPD 18 & 25 & 0 & 0 & 0 & 0 & 4 & 16 & 3 \\
\hline Total & & 126 & 8 & 6.34920 & & & 8 & 6.34920 & 12 \\
\hline
\end{tabular}


In the patient group, the smallest size fragments of ABCG2 were recorded at OPD18 (20-30) bp while the highest size fragments were recorded at OPAA11and OPU15 (990-1000) bp in size, compared with control group the smallest size fragments were recorded at (60 -70) bp at all primers and the highest size fragments were recorded at OPU15 (1090-1100) bp. Our results showed that the primer OPD 18 showed the molecular weight (20-30) bp of the $A B C G 2$ bands in the patient group and its absence from the control group, as shown in figure (3).

In the patient sample, the smallest size fragments of $A B C B 1$ were recorded at OPAA17 (20-30) bp, while the highest size fragments were recorded at OPAA11 (990-1000) bp. The control sample revealed smallest size fragments at OPAA11, OPU15, and OPD18 (20-30) bp and the highest size fragments were recorded at

OPAA11, OPD18 (290 - 300) bp. Our results showed that the primer OPAA17 showed that the molecular weight (20-30)bp in the patient group and its absence from the control group, as shown in figure (4).

In patient group, the smallest size fragments of BRCA1 were recorded at OPAA17 20-30 bp while the highest size fragments were recorded at OPU15 990-100 $\mathrm{bp}$ in size, compared with the control group the smallest size fragments were recorded at all primer 50-60 bp and the highest size fragments were recorded at OPAA17 (1090 -1100) bp in size. Our results showed that the primer OPAA17 showed the molecular weight 20-30 bp in the patient group and its absence from the control group, as shown in figure (5).

Our results showed that the highest total number of polymorphic band was 38 in $A B C B 1$ gene, and the least one was 27 in $B R C A 1$ gene. While the total number of unique band 19 in $B R C A 1$ gene, and the least one was 11 in $A B C B 1$ gene. The highest total number of monomorphic band 29 in $A B C G 2$ gene and the least one was 8 in $A B C B 1$ gene. The results of the statistical analysis by using Chi-square showed that there were no significant differences in the types of bands of the $A B C G 2, A B C B 1, B R C A 1$ between the patient sample and the control sample, at the probability level of $\mathrm{P}>0.05$, as shown in table (5), figure (6).

Table (5) statistical analysis for polymorphic, unique and monomorphic bands of $A B C G 2, A B C B 1, B R C A 1$ gene between patient and control samples.

\begin{tabular}{|c|c|c|c|c|c|c|}
\hline Gene & Type of band & $\begin{array}{l}\text { Overall } \\
\text { total } \\
\text { band }\end{array}$ & $\begin{array}{l}\text { Total No.of } \\
\text { band } \\
\text { (patient) }\end{array}$ & $\begin{array}{l}\text { Total No.of } \\
\text { band } \\
\text { (control) }\end{array}$ & $\mathrm{X} 2$ & P-value \\
\hline \multirow[t]{4}{*}{$A B C G 2$} & Polymorphic band & 29 & 15 & 14 & 1.593 & 0.451 \\
\hline & Unique band & 16 & 10 & 6 & & \\
\hline & Monomorphic band & 28 & 12 & 16 & & \\
\hline & Overall total & 73 & 37 & 36 & & \\
\hline \multirow[t]{4}{*}{$A B C B 1$} & Polymorphic band & 38 & 25 & 13 & 1.089 & \multirow[t]{3}{*}{0.580} \\
\hline & Unique band & 11 & 8 & 3 & & \\
\hline & Monomorphic band & 8 & 4 & 4 & & \\
\hline & Overall total & 57 & 37 & 20 & & \\
\hline \multirow[t]{4}{*}{$B R C A 1$} & Polymorphic band & 27 & 19 & 8 & 2.245 & \multirow[t]{3}{*}{0.325} \\
\hline & Unique band & 19 & 11 & 8 & & \\
\hline & Monomorphic band & 24 & 12 & 12 & & \\
\hline & Overall total & 70 & 42 & 28 & & \\
\hline
\end{tabular}

Our results showed that the total number of total bands of $E R$ - $a$ in the patient group was 298 band, the primer OPD18 gave the highest number of bands (86) band. In the patient group, the primer OPU15 was the least efficient in generating polymorphic bands 0.010 , as it gave only 3 polymorphic bands, this primer gave the lowest percentage of polymorphisms $3.7974 \%$ with a primer discriminatory power of $16.66 \%$, and it has the least primer discriminatory power, compared with the control group, the primer OPAA17 was the least efficient in generating polymorphic bands 0.054 , as it gave 7 polymorphic bands. Despite this, it is noted that the OPAD18 primer gave the lowest percentage of polymorphisms amounted to $20.4545 \%$ with a primer discriminatory power of $26.47 \%$. The lowest discriminatory power was $20.58 \%$ for OPAA 17 . The results showed that the total number of total bands of miRNA-152 gene was 149 band, the primer OPAA 11 was given the highest number of bands(43) bands out of the total bands, compared with control sample the total number of total bands was 93 band, the primer OPAA11 and OPAA17 were given the highest number of bands 24 bands out of the total bands, In the patient sample, the total number of the polymorphic band was 8 band, polymorphisms percentage was $5.369127 \%$, the four primer OPAA11, OPU15, OPAA 17 , and OPD 18 were given the same number of polymorphic band (2) band, compared with the control sample, the total number of the polymorphic band was 0 band, polymorphisms percentage was $0 \%$ In the patient sample, the four primers have the same primer efficiency $(0.013)$. It is noted that the primer OPD18 was given the highest percentage of polymorphisms amounted to (6.25\%) with a primer discriminatory power of (25\%), whereas the four primers have the same discriminatory power (25\%), compared with the control sample the four primers have the same primer efficiency (0), the primer discriminatory power for all primers was $0 \%$, as shown in table (6), figure (7). 
Table (6) The numbers and percentages of the total band ,polymorphic ,unique ,monomorphic band, and primer efficiency and primer discriminatory power that produced from amplified four primer RAPD in ER-a gene of control (healthy ) sample.

\begin{tabular}{|c|c|c|c|c|c|c|c|c|c|c|c|}
\hline Gene & $\begin{array}{l}\text { RAPD } \\
\text { Primer }\end{array}$ & $\begin{array}{l}\text { Total } \\
\text { No. of } \\
\text { bands }\end{array}$ & $\begin{array}{l}\text { Percentage } \\
\text { of primer } \\
\text { band } \\
\%\end{array}$ & $\begin{array}{l}\text { Total No. of } \\
\text { polymorphic } \\
\text { bands }\end{array}$ & $\begin{array}{l}\text { Primer } \\
\text { efficiency }\end{array}$ & $\begin{array}{l}\text { Polymorphis } \\
\text { ms \% }\end{array}$ & $\begin{array}{l}\text { Primer } \\
\text { discriminatory } \\
\text { power \% }\end{array}$ & $\begin{array}{l}\text { Total } \\
\text { No. of } \\
\text { unique } \\
\text { bands }\end{array}$ & $\begin{array}{l}\text { Uniqueness, } \\
\%\end{array}$ & $\begin{array}{l}\text { Total No. of } \\
\text { monomorphic } \\
\text { bands }\end{array}$ & $\begin{array}{l}\text { Mol } \\
\text { ms: }\end{array}$ \\
\hline \multirow{4}{*}{$\begin{array}{l}E R-a \\
\text { patient }\end{array}$} & OPAA11 & 81 & 27.18 & 5 & 0.016 & 6.1728 & 27.77 & 2 & 2.46913 & 4 & $4.9=$ \\
\hline & OPU15 & 79 & 26.51 & 3 & 0.010 & 3.7974 & 16.66 & 0 & 0 & 4 & $5.0 \epsilon$ \\
\hline & OPAA17 & 52 & 17.44 & 4 & 0.013 & 7.6923 & 22.22 & 1 & 3.84615 & 4 & $7.6 \subseteq$ \\
\hline & OPD18 & 86 & 28.85 & 6 & 0.020 & 6.9767 & 33.33 & 2 & 2.32558 & 4 & 4.65 \\
\hline Total & & 298 & & 18 & & 6.0402 & & 5 & 1.67785 & 16 & $5.3 \epsilon$ \\
\hline ER-a & OPAA11 & 18 & 14.06 & 8 & 44.4444 & 0.062 & 23.52 & 1 & 5.5555 & 0 & 0 \\
\hline \multirow[t]{3}{*}{ Control } & OPU15 & 41 & 32.03 & 10 & 24.3902 & 0.078 & 29.41 & 1 & 2.43902 & 0 & 0 \\
\hline & OPAA17 & 25 & 19.53 & 7 & 28 & 0.054 & 20.58 & 2 & 8 & 0 & 0 \\
\hline & OPD18 & 44 & 34.38 & 9 & 20.4545 & 0.070 & 26.47 & 3 & 6.8181 & 0 & 0 \\
\hline Total & & 128 & & 34 & 26.5625 & & & 7 & 5.46875 & 0 & 0 \\
\hline \multirow{4}{*}{$\begin{array}{l}\text { miRNA } \\
\text { patient }\end{array}$} & OPAA11 & 43 & 28.85 & 2 & 4.651162 & 0.013 & 25 & 1 & 2.32558 & 2 & 4.65 \\
\hline & OPU15 & 38 & 25.50 & 2 & 5.263157 & 0.013 & 25 & 1 & 2.631578 & 2 & $5.2 \epsilon$ \\
\hline & OPAA17 & 36 & 24.16 & 2 & 5.555555 & 0.013 & 25 & 0 & 0 & 2 & $5.5 \epsilon$ \\
\hline & OPD18 & 32 & 21.48 & 2 & 6.25 & 0.013 & 25 & 0 & 0 & 2 & 6.25 \\
\hline Total & & 149 & & 8 & 5.369127 & & & 2 & 1.342281 & 8 & $5.3 \epsilon$ \\
\hline $\operatorname{miRNA}$ & OPAA11 & 24 & 25.81 & 0 & 0 & 0 & 0 & 0 & 0 & 3 & 12.5 \\
\hline \multirow[t]{3}{*}{ Control } & OPU15 & 23 & 24.73 & 0 & 0 & 0 & 0 & 0 & 0 & 3 & 13.c \\
\hline & OPAA17 & 24 & 25.81 & 0 & 0 & 0 & 0 & 0 & 0 & 3 & 12.5 \\
\hline & OPD18 & 22 & 23.66 & 0 & 0 & 0 & 0 & 0 & 0 & 3 & $13 . \epsilon$ \\
\hline Total & & 93 & & 0 & 0 & 0 & 0 & 0 & 0 & 12 & $12 . c$ \\
\hline
\end{tabular}

In the patient group, the smallest size fragments of ER-a were recorded at OPAA11, OPD18 (40-50) bp while the highest size fragments were recorded at all primer (890-900) bp in size, compared with control sample the smallest size fragments were recorded at OPU15, OPAA17, and OPD18, the highest size fragments were recorded at OPAA11, OPU15, OPD18 (890-900) bp in size. The results showed that the primer OPAA11 showed the molecular weight (40-50) bp of the $E R-a$ bands in the patient group and its absence from the control group, as shown in figure (8).

In the patient sample, the smallest size fragments miRNA-152 were recorded at OPAA 17, OPD 18 (20-40) bp, while the highest size fragments were recorded at OPAA 11, OPU 15(290-300) bp in size, as shown in figure (4-28A), compared with control sample the smallest size fragments were recorded at all primer (50$60) \mathrm{bp}$ and the highest size fragments were recorded at all primer (170-180) bp. Our results showed that the primer OPAA 17, OPD 18 showed the molecular weight (20-40) bp of the mi-RNA 152 bands in the patient group and its absence from the control group, as shown in figure (9).

Our results showed that the highest total number of polymorphic band was 52 in $E R$ - $a$ gene, and the least one was 8 in $m i-R N A 152$ gene. While the total number of unique band 12 in ER-a gene, and the least one was 2 in mi-RNA 152 gene. The highest total number of monomorphic band 20 in mi-RNA 152 gene and the least one 16 in $E R$ - $a$ gene. The results of the statistical analysis by using Chi-square showed that there were significant differences in the types of bands of the ER- $a$, and miRNA-152 between the patient sample and the control sample, at the probability level of $P<0.05$, as shown in table (7), figure (10).

Table (7) statistical analysis for polymorphic, unique and monomorphic bands of ER-a gene between patient and control samples 


\begin{tabular}{|c|c|c|c|c|c|c|}
\hline Gene & Type of band & $\begin{array}{l}\text { Overall } \\
\text { total band }\end{array}$ & $\begin{array}{l}\text { Total No.of } \\
\text { band (patient) }\end{array}$ & $\begin{array}{l}\text { Total No.of } \\
\text { band } \\
\text { (control) }\end{array}$ & $\mathrm{X} 2$ & P-value \\
\hline \multirow[t]{4}{*}{$E R-a$} & Polymorphic band & 52 & 18 & 34 & \multirow[t]{3}{*}{21.220} & \multirow[t]{3}{*}{$0.000^{* * *}$} \\
\hline & Unique band & 12 & 5 & 7 & & \\
\hline & Monomorphic band & 16 & 16 & 0 & & \\
\hline & Overall total & 80 & 39 & 41 & & \\
\hline \multirow[t]{4}{*}{ mi-RNA 152} & Polymorphic band & 8 & 8 & 0 & \multirow[t]{3}{*}{10.000} & \multirow[t]{3}{*}{ 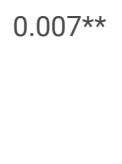 } \\
\hline & Unique band & 2 & 2 & 0 & & \\
\hline & Monomorphic band & 20 & 8 & 12 & & \\
\hline & Overall total & 30 & 18 & 12 & & \\
\hline
\end{tabular}

\section{Discussion}

Our PRP technique is a simple polymerase chain reaction product based gene polymorphism assay system that is used for study and analyzes genomic instability or genomic alteration. Novikov et al., (2016) mentioned that the RAPD is used in the field of studying genetic alteration of breast cancer. Boysen et al., (2019); Sabra et al., (2020) found that the genetic progress towards transformation from normal to malignant cells can be achieved by comparing the RAPD profiles obtained from healthy and malignant. RAPD technique is considered random with reduced reproducibility, we chose it as a rapid and low price technique (Bidet et al., 2000). However, we performed a new procedure with some modifications in the traditional RAPD technique when we used the amplified gene as a template in RAPD. This procedure resulted in a higher number of bands yielded with more accuracy and specific data. In the current study, we found that the number of bands per primer for each gene was high. This improved RAPD successfully increased the number of RAPD bands produced from a given PCR product. Therefore, we applied the RAPD technique with 5 specific genes ( $A B C B 1, A B C G 2, B R C A 1$, miRNA152,and ER- $a$ ) to generate more bands for detecting genomic alterations in human breast cancer.

The results showed that the total bands of the BC genes in the patient group were higher than the control group. Rocco et al., (2014) mentioned that the differences in the number of bands and the variations in their intensity, in the RAPD-PCR profile, are associated with alterations of genetic material. Liu et al., (2005) suggested that the modifications of band intensity and lost band are likely to be due to one or a combination of the following events: changes in oligonucleotide priming sites due mainly to genomic rearrangement, point mutations and DNA damage in the primer binding sites is only 10 base long, and interactions of DNA polymerase with damaged DNA. Our results showed there were significant differences $(P<0.05)$ between the patient and control group among polymorphic, unique, and monomorphic bands in the ER-a and mi-RNA 152 gene may be due to genetic alteration between the two groups. Singh and Roy (2001) stated the disappearance (deletion) or appearance (insertion) of an amplified DNA fragment might be associated with genetic rearrangements, or unequal mitotic recombination. Perrone et al., (2016) reported that the inherently predisposed reaction of DNA damage due to exogenous and endogenous factors that can be the development of hereditary diseases and sporadic cancer.

The results showed marked differences in the primer discriminatory power between patients and control group of the (ABCG2, $A B C B 1, B R C A 1, E R$ - $a$, and mi$R N A$ 152) genes, this differences may be due to the dependence of the primer discriminatory power on the number of polymorphic bands generated from each primer and the sum of the polymorphic bands generated from all primers. Ismaeel (2013) reported that the primer capacity to show polymorphisms in comparison to polymorphisms shown by all primers is called primer discriminatory power. The results showed marked differences in the primer efficiency between patients and the control group of the ( $A B C G 2, A B C B 1, B R C A 1, E R-a$, and mi-RNA 152) genes, these differences may be due to the dependence of the primer efficiency on the number of polymorphic bands generated from each primer and the sum of the bands generated from all primers, so the primer efficiency was variable between the patient and control group. Newton and Graham., (1997); Ismaeel (2013) stated that the primer efficiency values range from (0-1) and are defined as the measure of the primer's ability to produce polymorphisms. Ibrahim and his team (2010) reported that the efficiency of the primer can be demonstrated by its ability to give the highest percentage of polymorphic bands compared to the total number of amplified bands, the important characteristic of the efficient primer is the ability to illustrate the polymorphism between normal individuals and patient individuals such as leukemia.

The results showed marked differences in the molecular size of fragments produced from primers between the patient and control group. The primer OPD18 showed the molecular weight (20-30) bp of the ABCG2 bands in the patient group and its absence from the control group. The primer OPAA 17 showed the molecular weight (20-30) bp of the $(A B C B 1, B R C A 1)$ bands in the patient group and its absence from the control group. The primer OPAA 11 showed the molecular weight (40-50) bp of the ER-a bands in the patient group and its absence from the control group. The primer OPAA 17, OPD 18 showed the molecular weight (20-40) bp of the (mi-RNA-152) bands in the patient group and its absence from the control group. Thus, the bands with their primers may rely upon in distinguishing between the patient and the control group genetically after studying them more in the future. Papadopoulos et al., (2002); Xian et al., (2005); Ibrahim and his team (2010) found that the polymorphism also includes the differences in molecular weights of amplified bands which resulted from multiple types of mutations and translocations that occurred, thus causing mobility shift of bands and might cause the addition of new band (s).

\section{Conclusions}


Our results proved the accuracy of our modification in the traditional RAPD technique, which yielded more specific bands related to genes, we conclude the success of use PCR-RAPD-PCR methods for first time in the studying genetic polymorphisms of the specific breast cancer related genes. Additionally, this test gave us an indication of high polymorphism in patients when compared to controls, which may be related to mutations or modifications. There were significant differences between patients and healthy women in regard to the expression of breast cancer related genes. High levels of estrogens may be the direct effector in the induction and promotion of breast cancer, and this hormone can be inserted into the body by different routes, such as contraceptive pills, cosmetics and xenoestrogens present in the environment. we suggested from our data that most breast cancers in Iraqi women are not family related but rather drug resistance and estrogen response. We conclude the presence molecular weights of some bands in the patients group and its complete absence from the control group can be considered as an indicator to breast cancer after studying it more at the molecular level. Therefore, We can predict and diagnose breast cancer early upon analysis of our chosen genes, and our study allows us to employ these genes in the early prediction of breast cancer.

\section{Declarations}

Ethical approval:

Informed consent: all patients and healthy women participated in the study were signed an informed consents prior the study (samples attached at the end of this file).

\section{Consent of publication:}

Authors declare their consent of publication

\section{Availability of data:}

Data available with correspondence author Maytham A Dragh, maithamdragh@uomisan.edu.iq

\section{Competing interests:}

Authors show no competing interests

\section{Funding:}

No funding was available

\section{Authors contributions:}

MAD designed the study and suggest the ideae of research. ZZG carried out the molecular genetic work and performed the statistical analysis . ZZG write the manuscript. All authors read and approved the final manuscript.

\section{Ethics of research:}

The study was performed under the rules of ministry of higher education and scientific experiments all the patients in which samples were obtained were awaring of the goals of the study and were agree for giving samples.

\section{ACKNOWLEDGEMENT}

Much deep thanks to Maysan Health Directorate/ AL-Sader Teaching Hospital /AL-Shifa Tumor Treatment Center especially Assist. Prof. Dr. Haider Sadun Qasim and all the staff of the /AL-Shifaa Tumor Treatment center for facilitating the approval of the collection of blood samples and providing support to graduate students. My thanks and appreciation to all breast cancer women patients and normal people for their consent to draw blood samples from them. Also we would like to express thanks to the genetic engineering laboratory/Department of Biology/College of science/Misan University and all the staff of the genetic engineering laboratory.

\section{References}

1. Abd Ellatif, M., Zahran, M. A., Denaiwar, A., Elbaz, A., \& Abdel Azeez, H. A. (2016). Study of polymorphism of the estrogen receptor alpha gene as a genetic marker for the risk of breast cancer.

2. Abuhaliema, A. M., Yousef, A. M. F., El-Madany, N. N., Bulatova, N. R., Awwad, N. M., Yousef, M. A., \& Al Majdalawi, K. Z. (2016). Influence of genotype and haplotype of MDR1 (C3435T, G2677A/T, C1236T) on the incidence of breast cancer-a case-control study in Jordan. Asian pacific journal of cancer prevention, 17(1), 261-266.

3. Al Hannan, F., Keogh, M. B., Taha, S., \& Al Buainain, L. (2019). Characterization of BRCA1 and BRCA2 genetic variants in a cohort of Bahraini breast cancer patients using next-generation sequencing. Molecular genetics \& genomic medicine, 7(7), 771-779.

4. Al-Amri, R. J., Alotibi, M. K. H., Al-Raddadi, R. I., Shebli, W. T. Y., Fallatah, E. I. Y., Alhujaily, A. S., \& Mohamed, H. S. (2020). Estrogen Receptor 1 Gene (ESR1) rs2234693 Polymorphism and Breast Cancer Risk in Saudi Women. Asian Pacific Journal of Cancer Prevention, 21(11), 3235-3240.

5. Ayub, S. G., Rasool, S., Ayub, T., Khan, S. N., Wani, K. A., \& Andrabi, K. I. (2014). Mutational analysis of the BRCA2 gene in breast carcinoma patients of Kashmiri descent. Molecular medicine reports, 9(2), 749-753. 
6. Bidet, P., Lalande, V., Salauze, B., Burghoffer, B., Avesani, V., Delmée, M., ... \& Petit, J. C. (2000). Comparison of PCR-ribotyping, arbitrarily primed PCR, and pulsed-field gel electrophoresis for typing Clostridium difficile. Journal of clinical microbiology, 38(7), 2484.

7. Boysen, L., Viuff, B. M., Landsy, L. H., Price, S. A., Raymond, J. T., Lykkesfeldt, J., \& Lauritzen, B.

(2019). Formation and glomerular deposition of immune complexes in mice administered bovine serum albumin: Evaluation of dose, frequency, and biomarkers. Journal of immunotoxicology, 16(1), 191-200.

8. Choudhari, S , K.,Chaudhary ,M.,Gadbail,A.R.,Sharma,A.,\&Tekade,S.(2014) .Oxidative and antioxidative mechanisms in oral cancer and precancer : a review .oral oncology ,50(1),10-18.

9. Gholipoorfeshkecheh, R., \& Arjunan, S. (2014). Genotyping frequent BRCA1 SNPs in familiar breast cancer in Indian population by restriction fragment length polymorphism and sequencing. Adv App/ Sci Res, 5, 262-267.

10. Ibrahim M, Saleh N, Archoukieh E, Al-Obaide H, Al-Obaidi M, Said H. Detection of Novel Genomic.(2020). Polymorphism Detection of Novel Genomic Polymorphism in Acute Lymphoblastic Leukemia by Random Amplified Polymorphic DNA Analysis. J. can. Res., 6, 19-26.

11. Ismaeel, H. M. (2013). Identification of genomic markers by RAPD-PCR Primers in Iraq Breast Cancer patients. Iraq J Sci, 54, 97-104.

12. Jin, Y. (2020). Blood DNA methylation as a surrogate epigenetic biomarker in study of night shift work and breast cancer.

13. Kindrat, I., Tryndyak, V., de Conti, A., Shpyleva, S., Mudalige, T. K., Kobets, T., ... \& Pogribny, I. P. (2016). MicroRNA-152-mediated dysregulation of hepatic transferrin receptor 1 in liver carcinogenesis. Oncotarget, 7(2), 1276-1287.

14. Kumar, N. S., \& Gurusubramanian, G. (2011). Random amplified polymorphic DNA (RAPD) markers and its applications. Sci Vis, 11(3), $116-124$.

15. Liu, W., Li, P. J., Qi, X. M., Zhou, Q. X., Zheng, L., Sun, T. H., \& Yang, Y. S. (2005). DNA changes in barley (Hordeum vulgare) seedlings induced by cadmium pollution using RAPD analysis. Chemosphere, 61(2), 158-167.

16. Liu, X., Li, J., Qin, F., \& Dai, S. (2016). miR-152 as a tumor suppressor microRNA: Target recognition and regulation in cancer. Oncology letters, 11(6), 39113916.

17. Mampunye, L. (2020). MammaPrint risk score distribution in breast cancer patients with BRCA1/2 mutations (Doctoral dissertation , Cape Peninsula University of Technology).

18. Mehrgou, A., \& Akouchekian, M . (2016). The importance of BRCA1 and BRCA2 genes mutations in breast cancer development. Medical journal of the Islamic Republic of Iran, 30, 369-381.

19. Mohammed, Z. A. M. (2011). Determination of Serum IL-8 Level in Women with Breast Cancer and Their Correlation With Disease Progression. Iraqi Journal of Cancer and Medical Genetics, 4(2) , 43-46.

20. MUTLU içDUYGU, F., ŞAMLI, H., EVRENSEL, T., ÖZGÖZ, A., HEKIMLER ÖZTÜRK, K., CANHOROZ, M., ... \& IMIRZALIOĞLU, N. (2020). ASSOCIATION BETWEEN MDR 1 (ABCB1) GENE C3435T, C1236T, G2677T/A, A2956G POLYMORPHISMS AND THE RISK OF BREAST CANCER AMONG TURKISH WOMEN. Medical Journal of Suleyman Demirel University, 27(3), 345-352.

21. Ndiaye, R., Diop, J. P. D., Bourdon-Huguenin, V., Dem, A., Diouf, D., Dieng, M. M., ... \& Dieye, A. (2020). Evidence for an ancient BRCA 1 pathogenic variant in inherited breast cancer patients from Senegal. NPJ genomic medicine, 5(1), 1-6.

22. Newton, C.R. and Graham, A. 1997. Polymerase Chain Reaction. Bios Scientific publishers. Oxford, UK.

23. Novikov, V. V., Shumilova, S. V., Novikov, D. V., Kalugin, A. V., Fomina, S. G., \& Karaulov, A. V. (2016). Genetic Instability in Locus rs5498 E469K (A/G) of ICAM-1 Gene in Patients with Colorectal Cancer and Breast Cancer. Bulletin of experimental biology and medicine, 160(6), 811-813.

24. Papadopoulos, S., Benter, T., Anastassiou, G., Pape, M., Gerhard, S., Bornfeld, N., ... \& Dörken, B. (2002). Assessment of genomic instability in breast cancer and uveal melanoma by random amplified polymorphic DNA analysis . International journal of cancer, 99(2), 193-200.

25. Perrone, S., Lotti, F., Geronzi, U., Guidoni, E., Longini, M., \& Buonocore, G. (2016). Oxidative stress in cancerprone genetic diseases in pediatric age: the role of mitochondrial dysfunction. Oxidative medicine and cellular longevity, $2016,1-7$.

26. Rebbeck, T. R., Friebel, T. M., Mitra, N., Wan, F., Chen, S., Andrulis, I. L., ... \& KConFab Investigators. (2016). Inheritance of deleterious mutations at both BRCA1 and BRCA2 in an international sample of 32,295 women. Breast Cancer Research, 18(1), 1-19.

27. Rocco, L., Valentino, I. V., Scapigliati, G., \& Stingo, V. (2014). RAPD-PCR analysis for molecular characterization and genotoxic studies of a new marine fish cell line derived from Dicentrarchus labrax. Cytotechnology, 66(3), 383-393.

28. Sabra, S. A., Saad, A. A., Abd El Moneim, N. A., Hemida, M. A. E. A., Moussa, N., \& Haroun, M. (2020). Evaluation of breast cancer regarding molecular and immunochemical markers. International Journal of Immunotherapy and Cancer Research, 6(1), 001-009.

29. Sambrook, J. F. and Russell, D. W. (2006). Detection of DNA in agarose gels. Cold Spring Harbor Protocols, 2006(1), pdb-prot4022.

30. Sas-Korczyńska, B., Kamzol, W., Kołodziej-Rzepa, M., \& Wysocki, W. M. (2017). The characteristics of breast cancer patients with metachronous primary malignancies. Journal of Oncology, 67(1), 14-23.

31. Sato, H., Nogueira-de-Souza, N. C., D'Amora, P., Silva, I. D., Girão, M. J., \& Schor, E. (2008). Intron 1 and exon 1 alpha estrogen receptor gene polymorphisms in women with endometriosis. Fertility and sterility, 90(6), 2086-2090.

32. Sharma, M., \& Singh, D. (2017). Utility of random amplified polymorphic DNA (RAPD) in forensic entomology. Int J Sci Res Sci Technol, $3(1)$, 56-58.

33. Sheng, X., Zhang, L., Tong, N., Luo, D., Wang, M., Xu, M., \& Zhang, Z. (2012). MDR1 C3435T polymorphism and cancer risk: a meta-analysis based on 39 case-control studies. Molecular biology reports, 39(7), 7237-7249.

34. Singh, K. P., \& Roy, D. (2001). Identification of novel breast tumor-specific mutation (s) in the q11. 2 region of chromosome 17 by RAPD/AP-PCR fingerprinting. Gene, 269(2), 33-43. 
35. Sun, Y. S., Zhao, Z., Yang, Z. N., Xu, F., Lu, H. J., Zhu, Z. Y., ... \& Zhu, H. P. (2017). Risk factors and preventions of breast cancer. International journal of biological sciences, 13(11), 1387.

36. Tazzite, A., Kassogue, Y., Diakité, B., Jouhadi, H., Dehbi, H., Benider, A., \& Nadifi, S. (2016). Association between ABCB1 C3435T polymorphism and breast cancer risk: a Moroccan case-control study and meta- analysis. BMC genetics, 17(1), 1-11.

37. Wu, H., Liu, Y., Kang, H., Xiao, Q., Yao, W., Zhao, H., ... \& Wei, M. (2015). Genetic variations in ABCG2 gene predict breast carcinoma susceptibility and clinical outcomes after treatment with anthracycline- based chemotherapy. BioMed research international, 279109-279121.

38. Xian, Z. H., Cong, W. M., Zhang, S. H., \& Wu, M. C. (2005). Genetic alterations of hepatocellular carcinoma by random amplified polymorphic DNA analysis and cloning sequencing of tumor differential DNA fragment. World Journal of Gastroenterology: WJG, 11(26), 4102.

39. Xie, Z. (2020). A systematic review: breast cancer susceptibility genes. In E3S Web of Conferences (Vol. 218). EDP Sciences.

40. Zhou, X., Zhao, F., Wang, Z. N., Song, Y. X., Chang, H., Chiang, Y., \& Xu, H. M. (2012). Altered expression of miR-152 and miR-148a in ovarian cancer is related to cell proliferation. Oncology reports, 27(2), 447- 454.

\section{Figures}
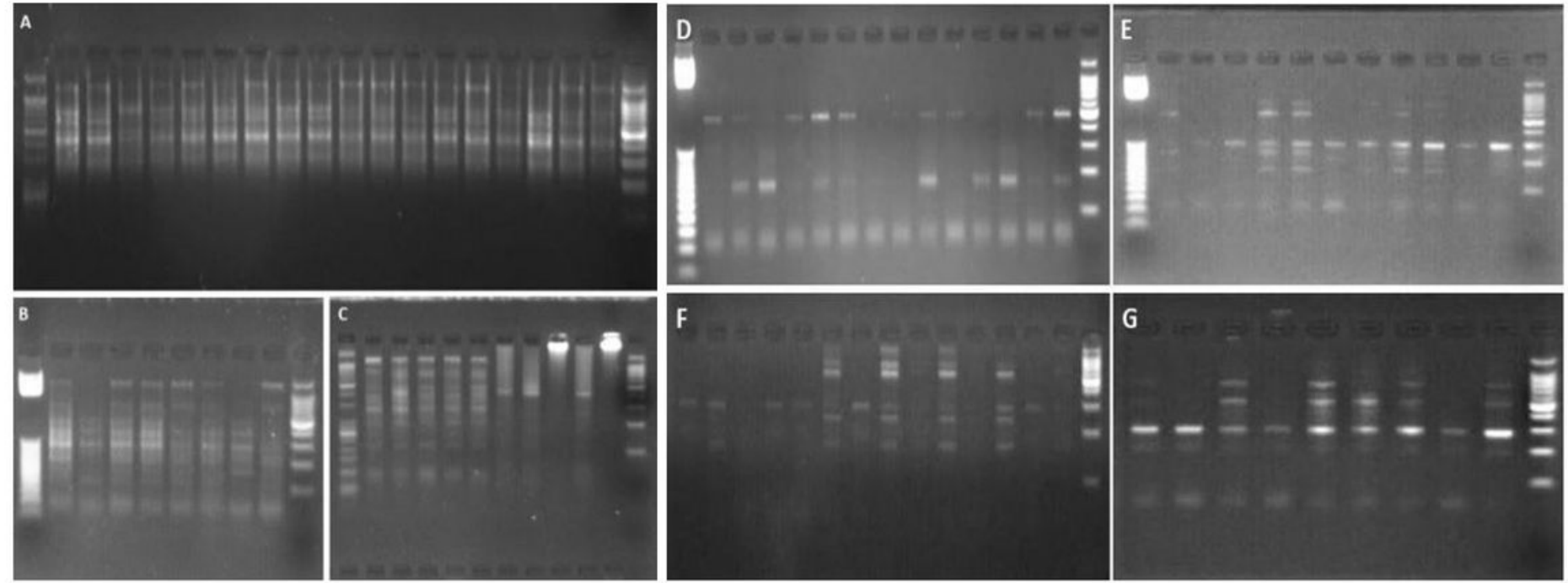

\section{Figure 1}

PCR assay for BC related genes with RAPD primer. Agarose gel of $2 \%$ loaded with DNA ladder of (25-1100 bp) and four RAPD primers OPAA11, OPU 15, OPAA17 and OPD18 were used. 


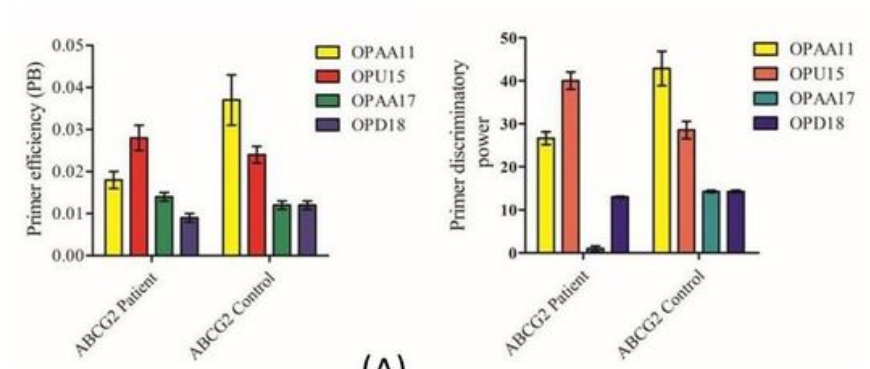

(A)

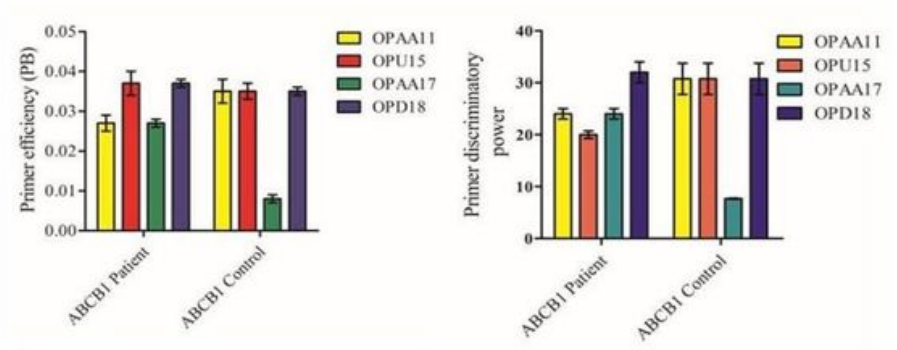

(B)

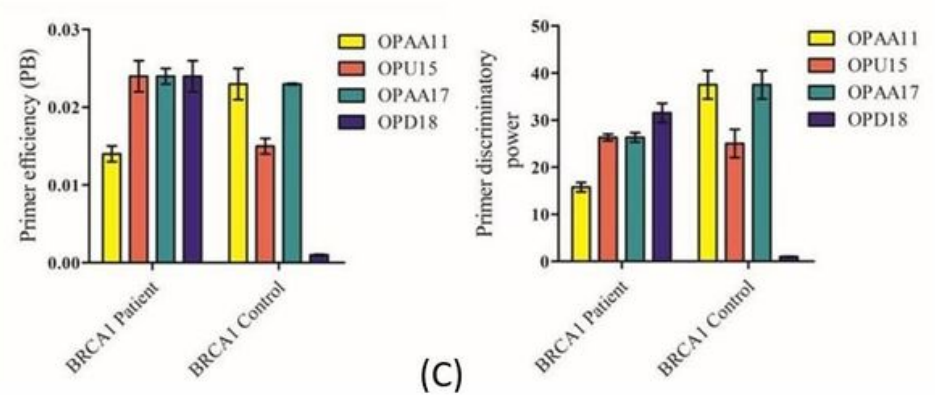

Figure 2

A primer efficiency and discriminatory in $A B C G 2$ gene of $B C$ patient and control. B primer efficiency and discriminatory in $A B C B 1 \mathrm{gene}$ of $\mathrm{BC}$ patient and control. C primer efficiency and discriminatory in BRCA1 gene of $\mathrm{BC}$ patient and control.
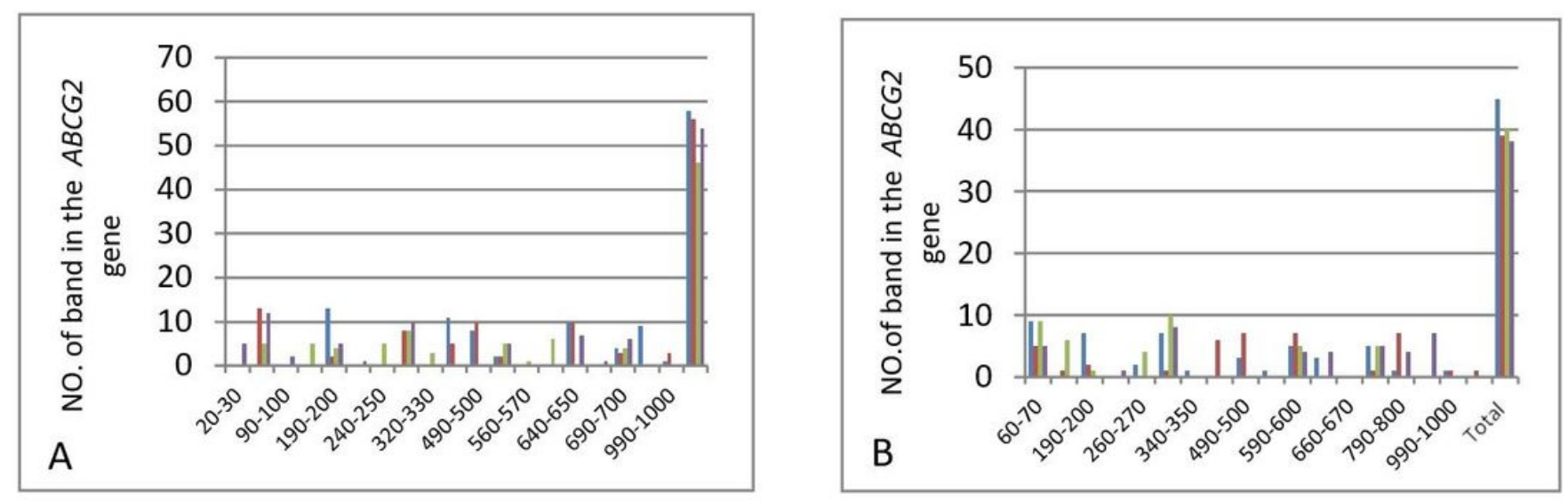

Figure 3

A size range of the fragments in $A B C G 2$ gene of $\mathrm{BC}$ patient. B size range of the fragments in $A B C G 2$ gene of control 

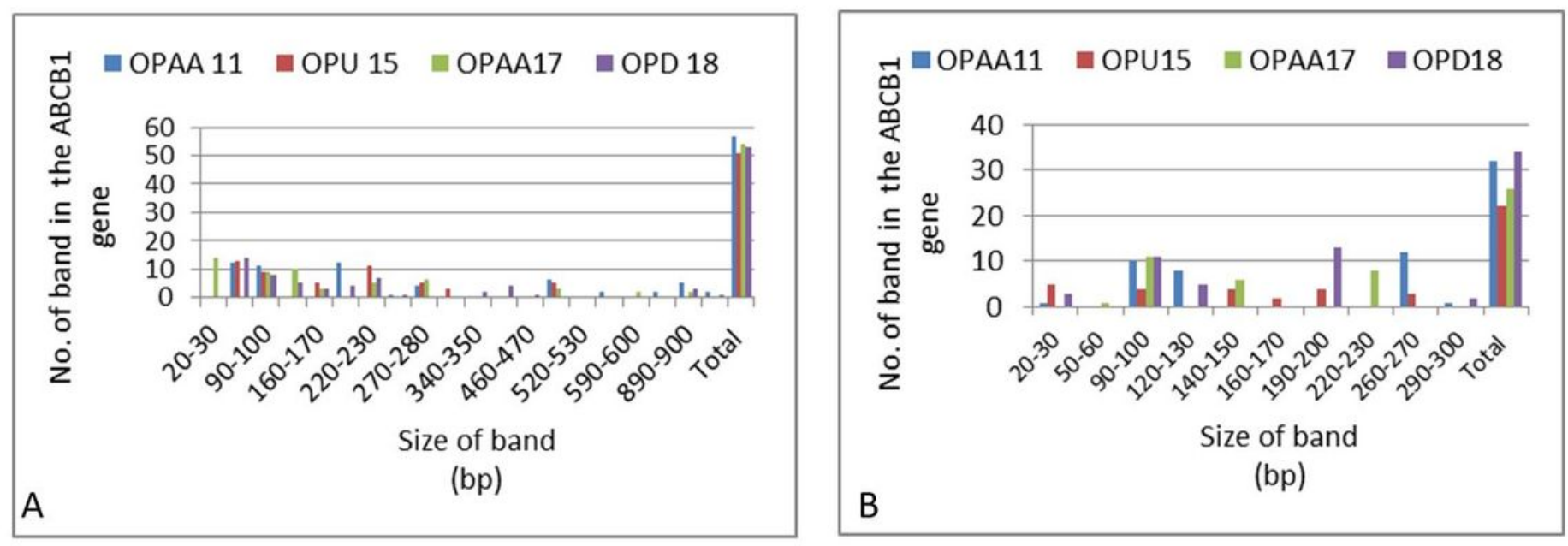

Figure 4

A size range of the fragments in $A B C B 1$ gene of $\mathrm{BC}$ patient. $\mathrm{B}$ size range of the fragments in $A B C B 1$ gene of control
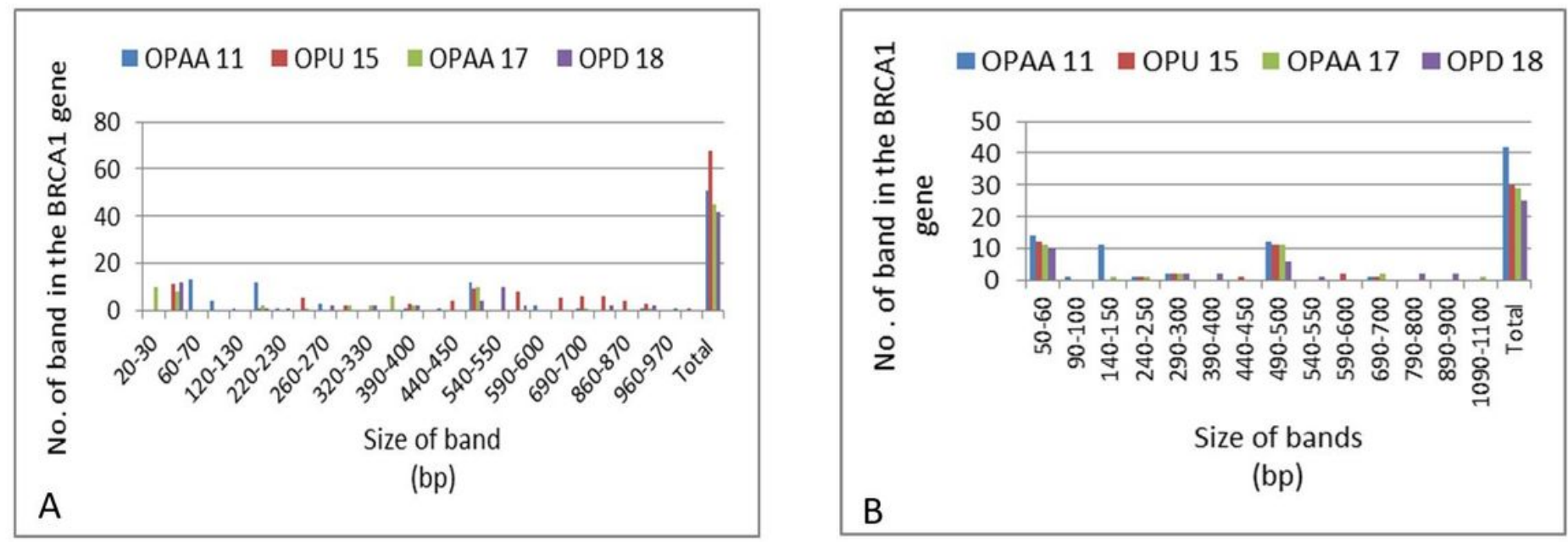

Figure 5

A Size range of the fragments in $B R C A 1$ gene of $\mathrm{BC}$ patient. B Size range of the fragments in $B R C A 1$ gene of control
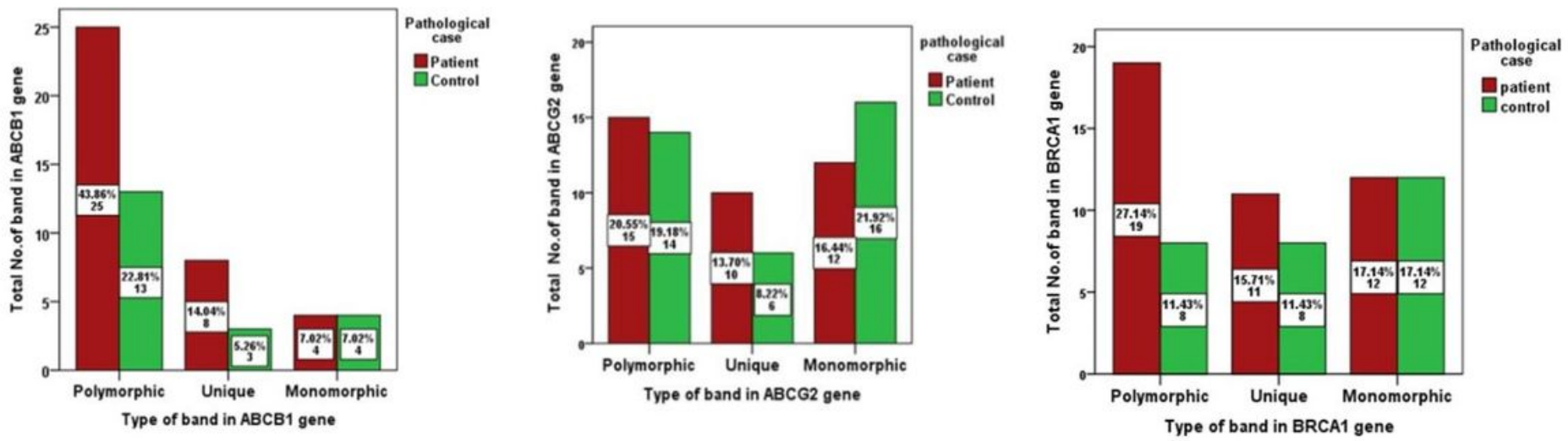

Figure 6 
Statistical numbers and percentages of the total polymorphic, unique and monomorphic bands of $A B C G 2, A B C B 1, B R C A 1$ gene between $B C$ patient and control.

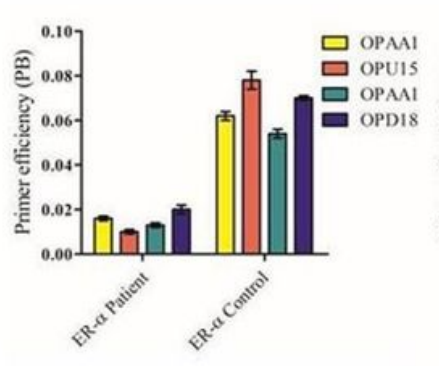

(A)

)

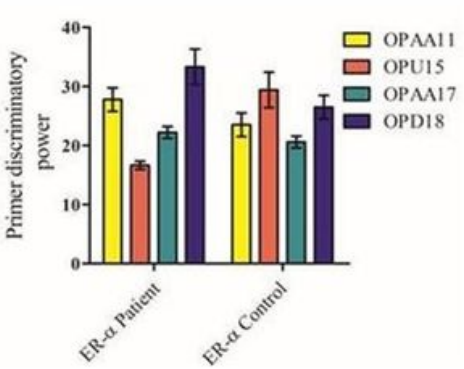

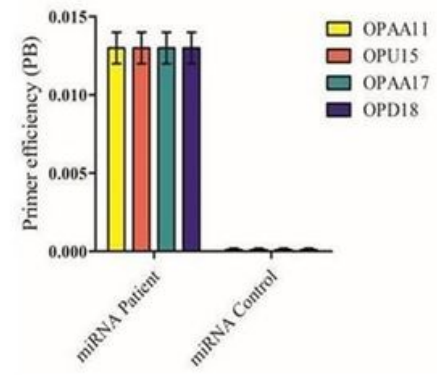

(B)

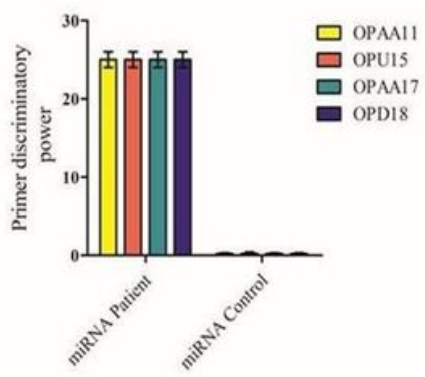

Figure 7

A. primer efficiency and discriminatory in ER- $a$ of $\mathrm{BC}$ patient and control .(B) primer efficiency and discriminatory in miRNA-152 genes of BC patient and control .
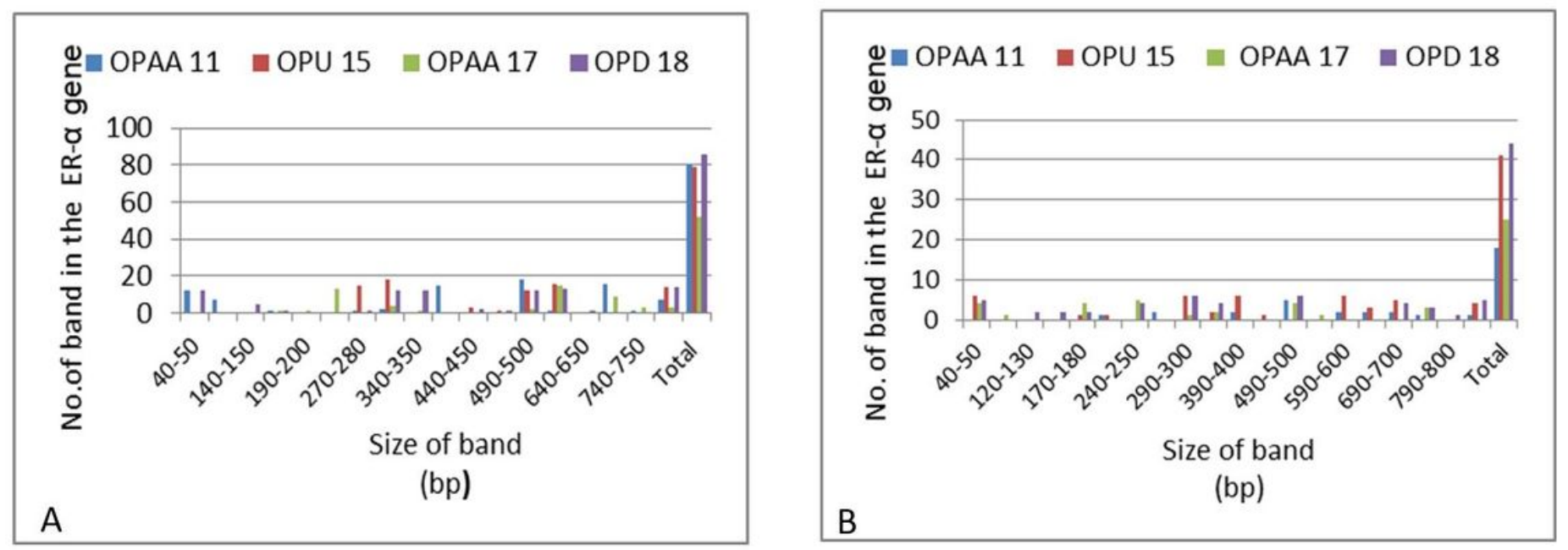

Figure 8

A size range of the fragments in $E R$ - $a$ gene of $\mathrm{BC}$ patient. B size range of the fragments in $E R$ - $a$ gene of control
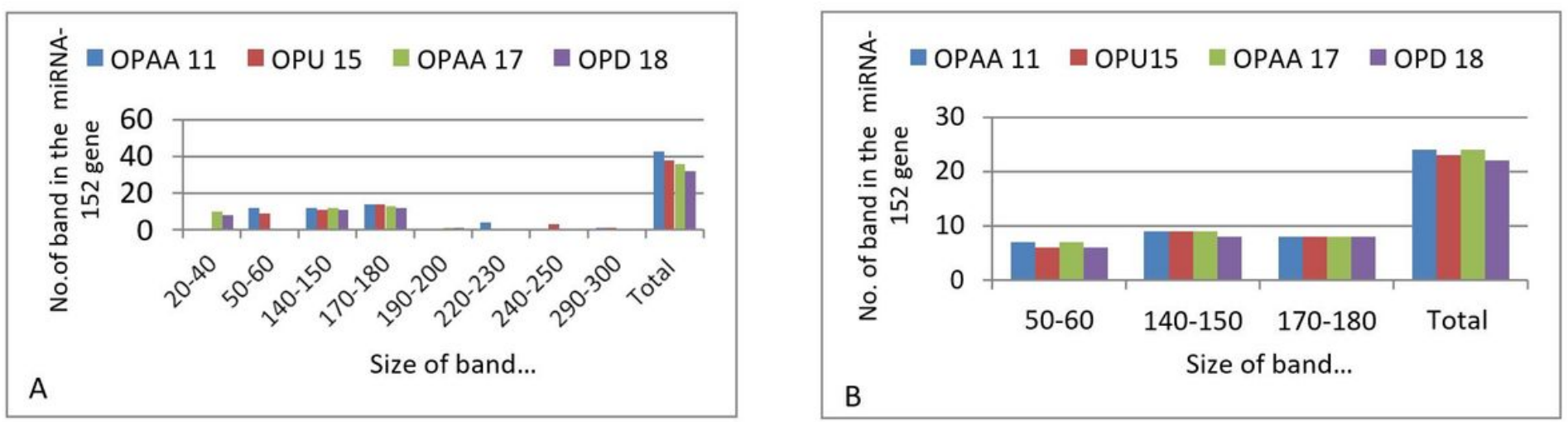

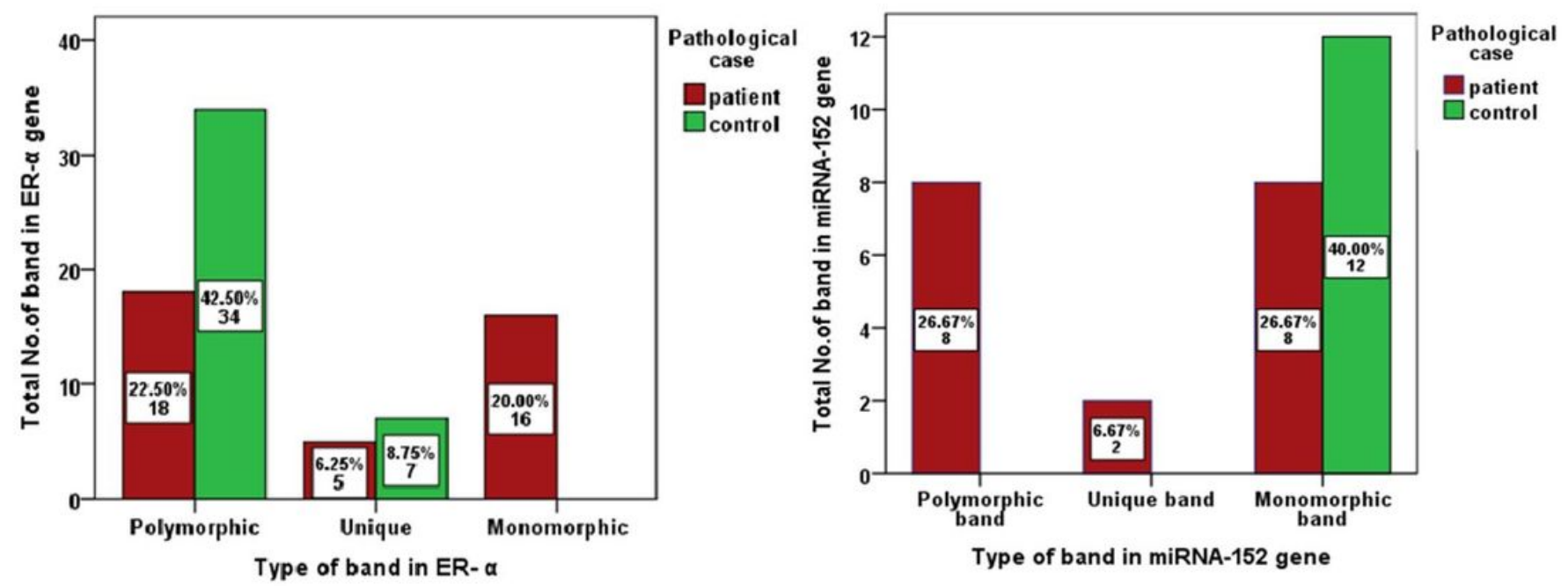

Figure 10

Statistical numbers and percentages of the total polymorphic,unique and monomorphic bands of $E R$ - $a$, and miRNA-152 gene between BC patient and control. 